\title{
B-cell selection and the development of autoantibodies
}

\author{
Natalia V Giltiay ${ }^{1+}$, Craig P Chappell ${ }^{1+}$ and Edward A Clark ${ }^{* 1,2}$
}

\begin{abstract}
The clearest evidence that B cells play an important role in human autoimmunity is that immunotherapies that deplete B cells are very effective treatments for many autoimmune diseases. All people, healthy or ill, have autoreactive B cells, but not at the same frequency. A number of genes influence the level of these autoreactive $B$ cells and whether they are eliminated or not during development at a central checkpoint in the bone marrow (BM) or at a later checkpoint in peripheral lymphoid tissues. These genes include those encoding proteins that regulate signaling through the B-cell receptor complex such as Btk and PTPN22, proteins that regulate innate signaling via Toll-like receptors (TLRs) such as MyD88 and interleukin-1 receptor-associated kinase 4, as well as the gene encoding the activation-induced deaminase (AID) essential for B cells to undergo class switch recombination and somatic hypermutation. Recent studies have revealed that TLR signaling elements and AID function not only in peripheral B cells to help mediate effective antibody responses to foreign antigens, but also in the BM to help remove autoreactive B-lineage cells at a very early point in B-cell development. Newly arising B cells that leave the BM and enter the blood and splenic red pulp can express both AID and TLR signaling elements like TLR7, and thus are fully equipped to respond rapidly to antigens (including autoantigens), to isotype class switch, and to undergo somatic hypermutation. These red pulp B cells may thus be an important source of autoantibody-producing cells arising particularly in extrafollicular sites, and indeed may be as significant a source of autoantibody-producing cells as B cells arising from germinal centers.
\end{abstract}

\section{Introduction}

Patients with rheumatoid arthritis (RA), systemic lupus erythematosus (SLE) or other autoimmune diseases have been treated successfully with B-cell-depleting therapies [1-3], demonstrating the key role that cells in the B-cell lineage play in human autoimmune disorders. B-lineage cells may contribute to the development of autoimmunity either as antigen-presenting cells, cytokine-producing cells, or autoantibody (autoAb)-producing cells. The role of B cells in autoimmunity has been reviewed recently [4-6].

Pathogenic autoAbs generally have the following three properties: reactivity with autoantigens; the IgG isotype; and somatic mutations. Since most B cells giving rise to autoAbs have undergone isotype class switch recombination (CSR) and somatic hypermutation (SHM), which

\footnotetext{
${ }^{+}$Contributed equally to this review

*Correspondence: eaclark@u.washington.edu

'Department of Immunology, 1959 NE Pacific Street, University of Washington,

Seattle, WA 98195, USA

Full list of author information is available at the end of the article
}

both require activation-induced deaminase (AID) [7], many studies have focused on defining where in development B cells display autoreactivity and where they express AID and undergo CSR and SHM. In this review we focus on recent studies underscoring the importance of B-cell subpopulations and innate signaling pathways in the steps leading to B-cell dysregulation and autoimmunity.

\section{B-cell developmental stages and checkpoints}

$B$ cells arise in the bone marrow (BM), and after undergoing selection they enter the bloodstream and seed the periphery as immature B cells found in blood and in the red pulp (RP) of the spleen (Figure 1). Some of these immature $B$ cells are selected further to become mature follicular B cells, which in turn become memory B cells after exposure to antigen.

\section{Reactivity with autoantigens}

All humans have autoreactive B cells. The B-cell repertoire is created by random $\mathrm{V}(\mathrm{D}) \mathrm{J}$ gene recombination in $\mathrm{B}$-cell precursors within the $\mathrm{BM}$, which produces a population of newly formed $B$ cells with a highly diverse set of B-cell receptors (BCRs) (Figure 1). Human 


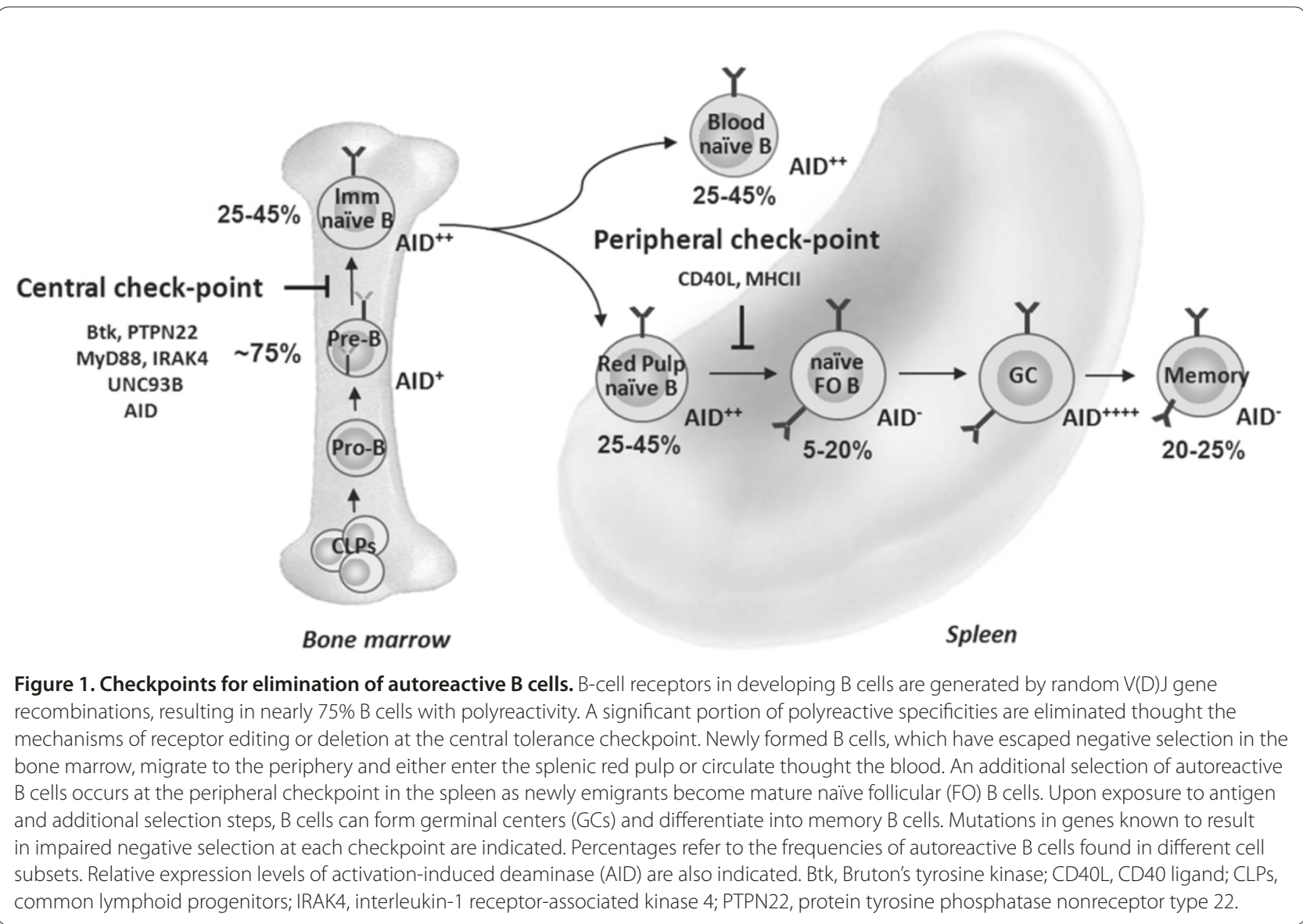

immature B cells in blood can be defined as $\mathrm{CD} 20^{+} \mathrm{CD} 27^{-}$ $\mathrm{CD} 38^{\mathrm{hi}} \mathrm{CD} 24^{\mathrm{hi}} \mathrm{CD} 10^{+}$cells and further subdivided into $\mathrm{CD} 21^{\text {lo }}$ and $\mathrm{CD} 21^{\text {hi }}$ populations [8]; the $\mathrm{CD} 21^{\text {lo }}$ subset based on several criteria is less mature and in vitro produces higher levels of autoAb. The human spleen contains the highest levels of the $\mathrm{CD} 21^{\text {lo }}$ subset [8]. Using a novel single-cell PCR method, Meffre and Wardemann found that $75 \%$ of recombinant antibodies cloned from single, very immature BM B cells were polyreactive; that is, they reacted with a number of self-antigens such as insulin, single-strand DNA and double-strand DNA, or were autoreactive as measured by binding to HEp-2 cells (a measure of anti-nuclear antibody) [5,9]. The frequency of autoreactive cells remains high ( 25 to $45 \%$ ) in slightly more mature BM B cells or in $\mathrm{CD} 2 \mathrm{O}^{+} \mathrm{CD} 10^{+} \mathrm{CD} 21^{\mathrm{lo}} \mathrm{IgM}{ }^{\mathrm{hi}} \mathrm{CD} 27^{-}$ immature blood B cells [5]. Transition from the immature B-cell phenotype to the so-called mature $\mathrm{CD} 20^{+} \mathrm{CD} 10^{-}$ $\mathrm{CD} 21^{\mathrm{hi}}{ }^{\mathrm{IgM}} \mathrm{H}^{\mathrm{hi}} \mathrm{CD} 27^{-}$phenotype leads the frequency of autoreactive B cells to decrease once again to 10 to $20 \%$. Based on these studies, the majority of autoreactive $B$ cells in the periphery of humans appear to be in the $\mathrm{CD} 21^{\text {lo }} \mathrm{B}$-cell population [10].

Based on these findings, Meffre, Wardemann and others have suggested that there are two major checkpoints where autoreactive B cells normally are eliminated (Figure 1): a checkpoint in the BM that eliminates polyreactive and autoreactive immature BM B cells, most probably through deletion and receptor editing [4-6]; and a checkpoint in the periphery where autoreactive B cells are eliminated as immature B cells become mature B cells. Dysregulation of either one or both of these checkpoints may occur in patients with autoimmune diseases including RA, SLE, Sjögren's syndrome and type 1 diabetes, who have elevated frequencies of autoreactive immature blood B cells $[5,11,12]$.

\section{B-cell receptor and Toll-like receptor signaling defects}

A systematic analysis of patients with immunodeficiency diseases has uncovered which signaling elements are necessary for each checkpoint to operate [5]. X-linked agammaglobulinemia patients with mutations in the Bruton's tyrosine kinase $(B t k)$ gene and patients with mutations in the protein tyrosine phosphatase nonreceptor type 22 (PTPN22) gene have an increased frequency of autoreactive immature B cells $[5,13]$. Both Btk and PTPN22 participate in BCR signaling pathways, and the mutations leading to increased levels of 
autoreactive immature B cells lead to reduced BCR signaling. For instance, the PTPN22 polymorphism $(\mathrm{C} 1858 \mathrm{~T})$ associated with increased autoreactive B cells leads to a substitution of tryptophan for arginine at residue 620 (R620W). This results in reduced binding of PTPN22 with the Csk kinase, yet paradoxically leads to lower B-cell responses [14]. One possibility is therefore that defective BCR signaling in these patients leads to fewer B cells being deleted or edited at a central tolerance checkpoint in the BM (Figure 1). However, the C1858T PTPN22 mutation may also promote autoimmunity via other pathways that regulate memory B-cell formation [15] and dendritic cell (DC) responsiveness [16]. Furthermore, although mutations in Btk and PTPN22 lead to intrinsic defects in B cells, they could also affect non-B cells because Btk or PTPN22 can function in signaling pathways not associated with the BCR [16,17]. Therefore, while genetic data strongly support the link between polymorphisms in PTPN22 and susceptibility to a number of autoimmune diseases including SLE, RA, type 1 diabetes, and autoimmune thyroiditis, further studies are needed to define where and how PTPN22 functions.

Patients deficient in key Toll-like receptor (TLR) signaling pathway elements such as the MyD88 adaptor protein, the interleukin-1 receptor-associated kinase 4 (IRAK4), and the UNC93B1 transporter also have elevated frequencies of polyreactive immature B cells [18]. These data suggest that TLR-mediated signals along with $B C R$ signals regulate whether autoreactive $B$ cells enter the immature B-cell pool. Defects in the selection of autoreactive B cells in MyD88-deficient and IRAK4deficient patients were associated with impaired receptor editing. Whether these effects are linked to one specific TLR has not yet been determined. UNC93B1 can physically associate with human TLR8 [19] and regulates TLR7/9 trafficking [18], and thus may affect responses to RNA and DNA.

The fact that TLR signaling pathways function in early selection steps leading to removal of autoreactive B cells is a remarkable and surprising finding given that prior studies have emphasized the role of TLR signals in promoting the activation and expansion of autoreactive $B$ cells in the periphery (see below). Somewhat paradoxically, despite the increased frequency of autoreactive B cells in the periphery, IRAK4-deficient, MyD88-deficient and UNC93B1-deficient patients do not develop autoAbs or autoimmune disease; this underscores the importance of TLRs in the activation of autoreactive B cells in the periphery and the generation of pathogenic autoAbs.

MyD88, IRAK4 and UNC93B1 are also needed in humans for the second B-cell checkpoint to work in the periphery; that is, for autoreactive $B$ cells to be reduced in what Meffre and colleagues define as $\mathrm{CD} 19^{+} \mathrm{CD} 10^{-}$ $\mathrm{IgM}^{+} \mathrm{CD} 27^{-}$mature naïve $\mathrm{B}$ cells. Furthermore, a recent study suggests that Btk plays a key role in regulating a peripheral B-cell checkpoint in mice [20]. Given that these signaling elements play an important role in central B-cell tolerance, however, it is not entirely clear to what extent the increased levels of autoreactive $B$ cells after the peripheral checkpoint reflect a defect in peripheral selection per se in MyD88-deficient, IRAK4-deficient and UNC93B1-deficient patients or whether they are a consequence of defective central tolerance.

An additional distinct set of signaling elements, including CD40 ligand (CD40L) and MHC class II, also appears to be required for the peripheral checkpoint. The reason for this is not entirely clear; one possibility is that CD40L and class II may be needed to activate regulatory $\mathrm{T}$ cells controlling peripheral B-cell tolerance [5], but this is just one speculation. Elevated levels of the B-cell prosurvival factor BLyS (B-cell activating factor (BAFF)) have also been suggested to play a role in promoting autoreactive B-cell survival at this checkpoint $[6,21,22]$. BAFF transgenic mice develop T-cell-independent lupuslike disease [23] in part by upregulating TLR7/9 expression in B cells. TLR7/9 ligands in turn may contribute to a break in peripheral B-cell tolerance by inducing BAFF expression in several cell types including synovial fibroblasts [24] as well as by increasing expression of the TACI and BAFFR receptors for BAFF $[23,25]$.

\section{Germinal centers and memory B-cell formation}

The classic T-cell-dependent humoral response leads to the formation of germinal center (GCs), where B cells expressing high-affinity receptors for antigens present on follicular dendritic cells (FDCs) as immune complexes are selected and become memory B cells or long-lived IgG-producing plasma cells (PCs) [26,27]. During this efficient selection process, AID is expressed and both CSR and SHM are activated [7]. While the end-goal of SHM is to generate B cells with increased affinity for foreign antigens, SHM also has the potential to contribute to the generation of autoreactive B cells. Does the process of $\mathrm{GC}$ formation contribute to the generation of B lineage cells producing high-affinity IgG autoAbs?

For some conditions, the answer to this question clearly is 'Yes'. Mice in which the FcyRIIB receptor gene had been deleted (FcgRIIB KO) develop high-affinity IgG autoAbs and an SLE-like disease [28]. These FcgRIIB KO mice have increased levels of autoreactive GC B cells including anti-nuclear antibody-expressing $\mathrm{B}$ cells that arose as a direct result of SHM. SHM has also been shown to play a major role in the generation of autoreactive antibody in a second lupus-prone mouse model [29], as well as in humans with SLE [30,31]. In addition to the role of AID and SHM in generating autoreactive GC B cells, dysregulated negative selection 
of GC B cells is required for development of autoAbproducing PCs. B-cell selection in GCs is normally mediated by antigen acquisition from FDCs followed by antigen presentation to rare CD4 T-follicular helper cells. Presentation to CD4 T-follicular helper cells is thought to be the limiting step in the selection process, allowing GC $B$ cells with high-affinity BCRs to outcompete loweraffinity $\mathrm{B}$ cells for antigen and subsequent CD4 Tfollicular helper cell help. Lack of sufficient survival signals both from FDCs (for example, antigen, ICAM-1, CD40L) and from CD4 T-follicular helper cells (for example, ICOS, CD40L, IL-21) can result in apoptosis, thereby deleting cells that have too low affinity for antigen to be competitive, or for which there is no cognate CD4 T-cell help. How autoreactive GC B cells escape this 'deletion by neglect' is not entirely clear, but could involve multiple mechanisms - including, for example, abnormalities that lead to excessive accumulation of CD4 Tfollicular helper cells in GCs [32] and B-cell intrinsic dysregulation of prosurvival factors in mice containing the Sle1 locus [33].

Despite selection mechanisms that result in deletion of autoreactive GC B cells, such cells do find their way into the periphery. This is inferred from observations that some $\mathrm{CD}_{27} 7^{+} \mathrm{IgG}^{+}$memory $\mathrm{B}$ cells in humans express $\mathrm{BCRs}$ that are polyreactive or self-reactive $[31,34]$. Although long-lived PCs are also derived from GCs, it is interesting to note that the frequency of polyreactive and self-reactive $\mathrm{PCs}$ in the $\mathrm{BM}$ is much lower compared with the circulating memory B-cell pool in both healthy individuals and mice [31,34], despite the fact that BM PCs harbor more somatic mutations [34,35]. These observations imply that selection of GC B cells into the long-lived PC pool requires an additional checkpoint for autoreactivity that is not required for memory B-cell fate. Selection of GC $\mathrm{B}$ cells to become meory cells can occur quite rapidly in mice (within the first week of the immune response) [36], whereas BM PCs are not detected until the second and third weeks. This suggests that GC B cells destined to become long-lived PCs have endured a longer time in the GC compared with memory B-cell precursors. The antibodies produced by autoreactive or polyreactive PCs in the BM are often not pathogenic; however, they may be predictive of later disease onset in some individuals, indicating that additional factors beyond auto $\mathrm{Ab}$ production are required for disease culmination [37]. Additionally, depletion of $B$ cells through antiCD20 mAbs such as rituximab is not effective for eliminating circulating autoAbs for certain autoimmune disorders including RA and SLE (reviewed in [38]). This implies that long-lived PCs, which are resistant to depletion with anti-CD20 mAbs, are the source of these antibodies in these particular autoimmune disorders.
Role of activation-induced deaminase in early B-cell stages and selection

Despite the importance of GCs as sites of SHM, a growing body of data has demonstrated that AID expression and the AID-associated activities CSR and SHM also occur in B-cell populations residing in the BM and RP of the spleen. Mao and colleagues showed nearly 10 years ago that immature B cells in the mouse express AID and have somatic mutations [39]. The mutation frequency was not changed in the absence of $\mathrm{T}$ cells, a finding confirmed in later studies [40,41]. Two subsequent studies showed that AID is in fact expressed at higher levels in immature B cells than in follicular B cells in the spleen $[40,41]$. Ueda and colleagues found that splenic $\operatorname{IgM}^{+} \mathrm{D}^{-}$immature $\mathrm{B}$ cells increased twofold to eightfold in number after they immunized mice with antigen in incomplete Freund's adjuvant, while follicular and marginal zone (MZ) B cells did not increase [41]. The immature B cells expressed both TLR4 and TLR9 and proliferated after stimulation with either lipopolysaccharide (TLR4L) or CpG (TLR9L). Remarkably, lipopolysaccharide or $\mathrm{CpG}$ also induced the immature B cells to become IgG-producing antibody-forming cells (AFCs) in a CD154-independent manner. Furthermore, when the immature B cells were adoptively transferred into mice, they were just as capable as follicular B cells of being induced by a bacterial vaccine to become AFCs. The immature B cells expressed Ig $\alpha$, Ig $2 \mathrm{a}$, and Ig $2 \mathrm{~b}$ germline transcripts $[40,41]$. This study demonstrated that the B-cell population that contains high frequencies of polyreactive $\mathrm{BCRs}$ (that is, immature $\mathrm{B}$ cells) [5] is also capable of responding to antigen and undergoing CSR and SHM. In other words, immature B cells have all the prerequisites and propensity to become IgG autoAbproducing cells. However, further studies are needed to assess whether immature B cells produce IgG autoAbs in vivo; and if so, whether the autoAb produced is pathogenic.

Recent data suggest that human immature B cells have similar properties to their murine counterparts. Carsetti's group showed that a significant fraction (26\%) of human immature (transitional) B cells expand and proliferate in response to bacterial CpG DNA (TLR9 ligand) [42]. As a result of such activation the immature B cells acquired a phenotype similar to $\operatorname{IgM}^{+}$memory B cells and carried somatic hypermutations. The authors propose that the ability of immature B cells to undergo SHM - and we would add CSR - may serve as a protective mechanism against bacterial infection early after birth, at a time when immature $B$ cells are the major type of $B$ cell in the periphery [31]. Interestingly most of the somatic mutations were introduced in $\mathrm{VH} 1$ and $\mathrm{VH} 4 / 6$ genes, which encode anti-CpG DNA specificity, suggesting that the resulting BCR signaling can cooperate with the TLR9 
signaling (see below). It is not known whether a nonbacterial (endogenous) DNA triggers a similar activation of immature B cells. However, analysis of immature B cells in patients with autoimmune diseases suggests that this cell subset could contribute to the production of pathogenic autoAb. For example, increased frequencies of immature blood B cells have been observed in patients with SLE and Sjögren's syndrome [12]. In mice, the propensity for immature $B$ cells to produce IgG2b and IgG2c is dramatically increased by overexpression of TLR7 (Giltiay NV, Chappell CP, Sun X, Kolhatkar N, Teal TH, Kim J, Agrawal N, Buecher MB, Hamerman JA, Clark EA and Elkon KB, manuscript submitted). A combination of increased levels of immature cells and TLR7 dysregulation could thus predispose immature B cells to produce autoAbs.

\section{Blood and red pulp B cells}

Newly arising B cells have been called immature or transitional based on the fact that they can give rise to other B-cell subsets. However, the fact that AID is intrinsically expressed in immature B cells - even from mice missing $\mathrm{T}$ cells, CD154 or the TLR signaling component IRAK4 - indicates that the term immature for these B cells is misleading. They are not simply precursors for other B cells, but rather are an innate Bcell pool in their own right, readily capable of responding rapidly to both antigen and TLR signaling and undergoing CSR, particularly under inflammatory conditions [41]. Kelsoe and coworkers propose that 'TI responses by $\mathrm{AID}^{+} \mathrm{im} / \mathrm{T} 1 \mathrm{~B}$ cells might produce Ab specificities, including autoreactive paratopes, unavailable in the mature follicular (MF) compartment' [41]. In other words, the immature circulating B cells and splenic RP B cells may be a major source of IgG autoAbs in autoimmune diseases.

The newly formed IgM ${ }^{\mathrm{lo}}$ cells that have recently left the $\mathrm{BM}$ and entered the circulation or spleen are also often referred to as transitional $\mathrm{B}$ cells, implying that these $\mathrm{B}$ cells are on their way to becoming something and do not have a fully developed function until they are selected to enter the mature B-cell pool. In fact, transitional B cells are capable of responding to antigen, particularly in conjunction with a TLR agonist, and can mature into AFCs and undergo CSR. Other B-cell populations capable of responding to antigen are often named based on their location as newly formed BM B cells, blood B cells, follicular B cells, follicular mature B cells or MZ B cells. We therefore wish to propose that an alternative and more accurate term for transitional 1 or immature $B$ cells would be RP B cells (Figure 1).

Remarkably, the RP B-cell genotype and gene expression profile appears to be highly conserved in evolution. Similar to RP mouse B cells, the VLR B-cell subset in evolutionarily distant lampreys, which can respond to antigens and secrete VLR-containing antibodies, also express TLR7, CXCR4, BCAP, IL-17R, and Syk as well as the cytosine deaminase CDA2, a possible AID precursor [43]. If in fact ontogeny recapitulates phylogeny, then the early developing blood and RP innate B cells in mammals may represent the conservation of VLR B cells found in lampreys.

\section{Role for activation-induced deaminase in central B-cell tolerance}

Recent studies strongly suggest that AID is not only important for key functions in peripheral B cells, but also plays a role in B-cell tolerance at the BM central checkpoint. First, new emigrant immature B cells as well as mature naive $\mathrm{B}$ cells from AID-deficient patients express an abnormal immunoglobulin repertoire and high frequencies of autoAbs, demonstrating that AID is required for normal establishment of central B-cell tolerance [44]. AID is expressed in early B cells not only in the spleen but also in the fetal liver and BM, and AID expression in early human B cells, as with mouse B cells [39-41], is upregulated by TLR signaling. AID is also essential for normal B-cell tolerance in mice. Kuraoka and colleagues established chimeric mice containing both wildtype $\mathrm{BM}$ and $\mathrm{BM}$ from Aicda-deficient (the gene encoding AID) mice (Aicda KO) [45]. Although the chimeric mice had similar levels of wildtype and Aicda $\mathrm{KO}$ myeloid cells and T cells, they had significantly more Aicda $\mathrm{KO}$ immature $\mathrm{B}$ cells and mature $\mathrm{B}$ cells than wildtype B cells. In other words, Aicda $\mathrm{KO}$ immature B cells have a selective advantage over wildtype immature B cells. Aicda mice also displayed a defect in removing autoreactive BM B cells. These data strongly suggest that the central tolerance BM checkpoint is defective without AID.

Just how AID functions to regulate the central checkpoint in the BM is unclear. While CSR does occur in newly developing $\mathrm{BM} \mathrm{B}$ cells, Mao and colleagues detected SHM in BM immature B cells [39]. This observation suggests that AID might facilitate mutations away from autoreactivity. Alternatively, through its cytidine deaminase activity, AID might demethylate DNA and thereby in some way regulate steps during either $\mathrm{V}(\mathrm{D}) \mathrm{J}$ recombination or receptor editing. Kuraoka and colleagues found that AID-deficient immature BM B cells are more resistant to $\mathrm{BCR}$-induced cell death than wildtype B cells, suggesting that AID may normally contribute to inducing DNA damage to ensure apoptosis at the central tolerance checkpoint [45]. One would not be surprised if AID has functions distinct from mediating SHM and CSR, given that an AID counterpart is expressed in lamprey B-lineage cells prior to the onset of CSR in evolution [43]. 


\section{Autoimmunity and extrafollicular antibody responses}

Although the process of SHM in GC B cells has the potential to generate autoreactive antibody mutants, GCs may not be the origin of all autoreactive $B$ cells that arise via SHM. Using a mouse model that recapitulates the production of anti-IgG rheumatoid factor autoAb, William and colleagues showed that B-cell activation and differentiation, including CSR and SHM, took place solely within extrafollicular regions of the spleen, namely the $\mathrm{RP}$ and MZ-associated bridging channels, but not in GCs (Figure 2) [46]. The SHM that takes place in a GC-independent fashion in this model of autoimmunity may be a unique feature of humoral responses against self-antigen.

Interestingly, similar to AID expression in RP B cells [41], extrafollicular rheumatoid factor responses in the above mouse model did not require $\mathrm{T}$ cells, although AFC numbers and autoAb production were quantitatively enhanced in the presence of CD4 T-cell help [47]. CD4 T cells have traditionally been thought necessary for CSR and SHM, yet recent studies have shown T-cell-independent CSR and SHM can be driven by CpG-engagement of TLR9, which is further enhanced by concomitant signaling through the BCR $[42,48]$. BAFF and a proliferationinducing ligand (APRIL) can also elicit T-cell-independent CSR [49]. Recruitment of MyD88 to the transmembrane activator TACI results in AID expression and CSR by activating NF- $\mathrm{kB}$ through a Toll-like signaling pathway, which is impaired in mice and humans lacking MyD88 or IRAK4 [50]. Whether extrafollicular B-cell activation and differentiation (including SHM) that takes place in the RP of the spleen is a general feature of autoAb responses in humans is not yet clear.

$\mathrm{B}$ cells are required for the organization of lymphoid structures in secondary lymphoid organs via surface lymphotoxin- $\alpha / \beta$ expression [51], and B-cell depletion in mice results in disruption of follicles [52]. This ability to drive the organization of lymphoid follicles is important in the context of autoimmunity because tertiary, ectopic lymphoid structures have been described in nonlymphoid tissues in multiple autoimmune disorders in both humans and mice [53,54]. Within these structures, FDCs apparently drive the activation of $\mathrm{B}$ cells and $\mathrm{T}$ cells, leading to local production of inflammatory cytokines and autoAbs. The processes of B-cell activation and differentiation do not necessarily need to occur within archetypal B-cell follicles of secondary lymphoid organs.

Why might some autoreactive B-cell responses initiate and progress in extrafollicular spaces, as opposed to the classical follicular GC memory pathway? The GC is a specialized microenvironment whereby FDCs, CD4 T cells, and $\mathrm{B}$ cells interact in a coordinated fashion to exchange cognate antigen and co-stimulatory signals $[26,27,55]$. Although not as well defined as GC structures, extrafollicular bridging channels in the spleen are also regions that contain a high concentration of DCs (MZ DCs, not FDCs) that are in juxtaposition with T cells and the apical poles of B-cell follicles [56]. Circulating lymphocytes, such as RP B cells, must pass through the bridging channel microenvironment when migrating into follicular regions of the spleen, thereby coming into close contact with MZ DCs (Figure 2). Similar to follicular GCs and ectopic GC-like structures, therefore, extrafollicular bridging channels are an optimal microenvironment whereby B cells, T cells, and DCs are in juxtaposition to one another.

Both B cells and DCs have been implicated as being critical antigen-presenting cells in autoimmune disorders. The contribution of DCs to autoimmunity is not well studied, but they are assumed to be critical for initiation and progression of disease due to their established role in priming $\mathrm{T}$ cells during responses to foreign antigens. MZ DCs, but not CD8 $\alpha^{+}$DCs located in $\mathrm{T}$-cell zones, express a wide variety of C-type lectin receptors [56] that are often involved in uptake and removal of apoptotic/dead cell debris [57], which has been implicated as a source of autoantigen [58]. Furthermore, due to their unique position in bridging channels, MZ DCs are optimally positioned to interact with multiple B-cell populations including circulating mature and immature B cells, MZ B cells, as well as RP B cells that have yet to undergo peripheral selection (Figure 2). These potential interactions are significant because DCs can have multiple direct effects on B cells that include $\mathrm{T}$ cell-independent CSR as well as supporting the survival of short-lived PCs through production of soluble mediators including IL-6, BAFF, and/or APRIL $[49,59,60]$.

Additionally, DCs can directly present antigen to B cells via a nondegradative recycling pathway following antigen internalization $[61,62]$. The precise contributions that DC/B-cell interactions make toward initiating or sustaining extrafollicular autoAb responses is unknown, but constitutive depletion of DCs in SLE-prone MRL.Fas ${ }^{\text {pr }}$ mice demonstrated a striking reduction in plasmablast and autoAb production [63]. This reduction was not due to a lack of CD4 T-cell activation because CD4 T cells were highly activated in the absence of DCs. The DCs were therefore critical for the development of autoAbproducing AFCs but not for the initiation of CD4 T-cell responses. Consistent with these findings, our laboratory has recently shown that delivery of antigen directly to MZ DCs in mice using a mAb resulted in extrafollicular B-cell activation via direct interaction with B cells, which led to the development of extrafollicular antibody responses [64]. One should note that autoAb production in the MRL.Fas ${ }^{l p r}$ mouse model is mainly derived from extrafollicular responses, which is not the case for all mouse lupus strains. Furthermore, the roles that DC 


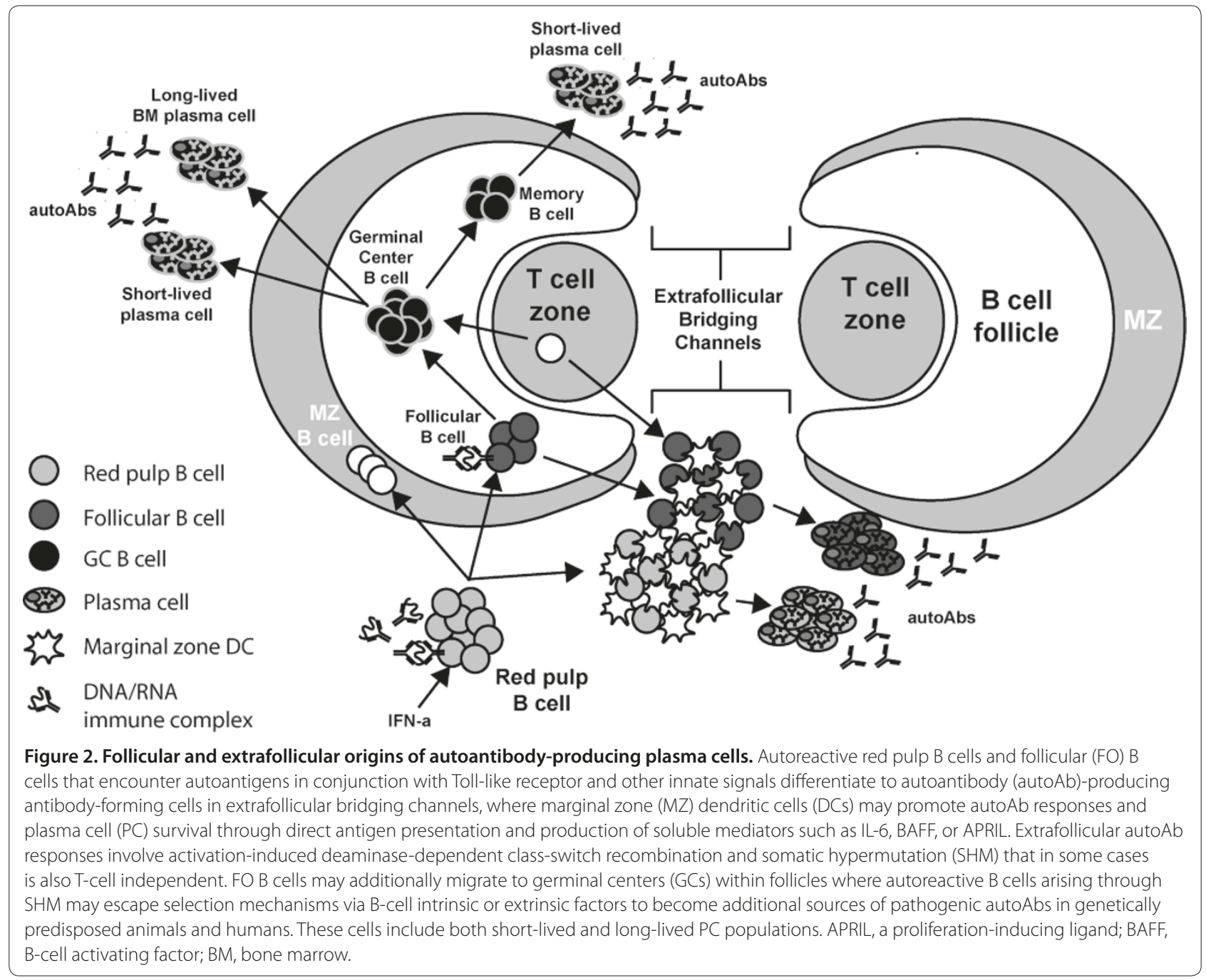

subsets play in human lupus are not clear. The importance of DCs in generating lupus-like disease and extrafollicular antibody responses therefore requires further study. Nevertheless, these findings suggest that depletion of one or more DC subsets may be an avenue of investigation for future immunotherapies aimed at ameliorating autoAb production derived from short-lived PCs.

\section{Regulation of B cells through TLR and type I interferon signals}

In this section we focus on the important role of innate signaling pathways involved in the activation of potentially autoreactive B cells, including both B-cell intrinsic and B-cell extrinsic signals (Figure 3).

\section{Intrinsic activation of B cells via TLRs}

As described above, despite the extensive negative selection of B cells both in the BM at a central checkpoint and at a peripheral checkpoint, a substantial portion of autoreactive specificities remain present in the peripheral B-cell pool. Most of these autoreactive B cells are HEp-2 reactive, suggesting that they carry specificities for DNAcontaining and/or RNA-containing ligands [5]. This is noteworthy since anti-nuclear autoAbs play a key role in the pathogenesis of SLE as they form immune complexes that deposit in the kidneys, blood vessels and skin. In addition, autoAbs can engage complement and Fc $\gamma \mathrm{R}$ on other cells, promoting local tissue inflammation.

What then are the underlying mechanisms leading to the activation of autoreactive B cells? Studies in murine autoimmune models have established that naive autoreactive $\mathrm{B}$ cells with low affinities for DNA-associated or RNA-associated antigens or rheumatoid factor, which have escaped the central and peripheral checkpoints, can be activated through dual engagement of their surface BCRs and intracellular DNA/RNA sensing receptors, such as TLR7 (single-strand RNA) and TLR9 
(CpG-DNA) [65-68]. The probable source of this endogenous RNA/DNA-containing material is cellular debris from dying/apoptotic cells or immune complexes, consisting of IgG, bound to mammalian chromatin or RNA-containing antigens. Increased cell death and insufficient clearance of dying cells have been implicated in the development of SLE [58]. Macrophages from SLE patients have an impaired ability to phagocytose apoptotic bodies [69,70]. Although mammalian DNA is considered a poor ligand for TLR9, modified (unmethylated) CpG-rich DNA may have high immunostimulatory potential [71]. Interestingly, some SLE patients have defects in DNA methylation [72], implying that they have higher levels of TLR9-activating ligands. Regarding specificity, TLR7 seems to be even less selective than TLR9 as it can recognize GU-rich sequences of singlestrand RNA from both viral and mammalian origin [73].

The mechanism by which B cells come in contact with and take up antigens in vivo is still unclear and probably depends on their location [74]. While it is possible for B cells to directly bind to nuclear-containing antigens exposed on the surface of cellular debris/apoptotic material, it is also likely that they bind antigens presented on the surface of DCs and macrophages [62,64]. Neutrophil extracellular traps might represent an additional source of nucleic-acid-containing cellular debris in SLE [75]. Recent studies have demonstrated that neutrophils can colonize peri-MZ areas of human spleens and induce CSR, SHM and antibody production through T-cellindependent mechanisms involving BAFF, APRIL and IL21 [76]. Furthermore, impaired neutrophil extracellular trap degradation has been associated with renal pathology in some SLE patients [75].

The splenic RP and MZ-associated bridging channels might represent key sites for the activation of polyreactive $B$ cells. Recent studies from our laboratory suggest that dysregulation of TLR7 expression in TLR7 transgenic mice drives the expansion and proliferation of newly emigrant RP B cells [77]. This abnormal activation is driven intrinsically by TLR7 in B cells, and is associated with upregulation of AID and increased production of antibodies - suggesting that when TLR7 signaling is dysregulated in RP B cells, they may produce IgG, including IgG autoAbs.

The exact molecular mechanisms mediated via the synergistic BCR/TLR engagement remain poorly understood. One current model suggests that, following binding to nucleic-acid-containing antigens, BCRs are internalized inside cells and antigen complexes are delivered to TLRs localized in the endosomal/lysosomal compartments (Figure 3). In a resting state, TLR9 is concentrated in the endoplasmic reticulum and redistributes from the endoplasmic reticulum to endosomes upon stimulation with CpG DNA [78]. Furthermore, BCR crosslinking followed by BCR internalization initiates a signal that recruits TLR9-containing endosomes into autophagosome compartments by utilizing microtubular networks and phospholipase D [79]. Several molecules have been implicated in the regulation of the TLR intracellular trafficking, including gp96, PRAT4A, and UNC93B1 [80]. UNC93B1, which can associate with TLR3, TLR7 and TLR9, may orchestrate TLR trafficking and plays a key role in regulating autoimmunity. Fukui and colleagues identified a mutation in mouse UNC93B1 that can shift its binding away from TLR9 to binding TLR7, which in turn leads to lethal inflammation and development of an SLE-like disease [18].

The relative contribution of individual TLRs in the development of SLE disease in mice has been a major focus of studies in the past few years. Marshak-Rothstein, Shlomchik and coworkers first reported the ability of chromatin/DNA-associated antigens to activate autoreactive $\mathrm{B}$ cells by the combination of BCR/TLR9 signals $[67,68]$. In a similar manner, dual engagement of BCR/TLR7 with RNA-associated antigens can mediate B-cell activation [66]. These studies predicted that deletion of either TLR7 or TLR9 would reduce the development of SLE disease in mice. However, follow-up studies suggested that TLR7 and TLR9 might have opposing functions in the regulation of SLE [81].

MLR/lpr lupus-prone mice deficient for TLR7 have a significant reduction in titers of autoAbs specific for RNA-associated autoantigens and develop less severe kidney pathology [81]. Increasing the Tlr7 gene dosage, on the contrary, promotes the development of murine SLE. The BXSB/MpJ mice - which carry the Y-linked autoimmune acceleration translocation of the locus encoding $T \operatorname{lr} 7$ (along with other genes) from the $\mathrm{X}$ chromosome onto the $\mathrm{Y}$ chromosome and have one extra copy of TLR7 - develop an SLE-like phenotype associated with production of anti-nuclear autoAbs and increased type I interferon. While Y-linked autoimmune acceleration mutation alone is insufficient to induce significant autoimmune disease, it greatly accelerates the development of SLE in lupus-prone FcyRIIB-/- mice [82]. Furthermore, increasing the $T l r 7$ gene dosage in TLR7 transgenic mice leads to an acute systemic autoimmune disease, characterized by myeloproliferative syndrome, glomerulonephritis and the production of anti-RNA autoAbs [83].

In contrast, the depletion of TLR9 in lupus-prone mice surprisingly accelerates disease development, suggesting a possible regulatory role for TLR9 in autoimmunity and SLE $[84,85]$. One explanation of this phenomenon is that TLR9 might function to regulate TLR7 responses. A possible contribution of TLR9 to early B-cell development and induction of central tolerance is also worth considering. TLR8, another single-strand RNA 


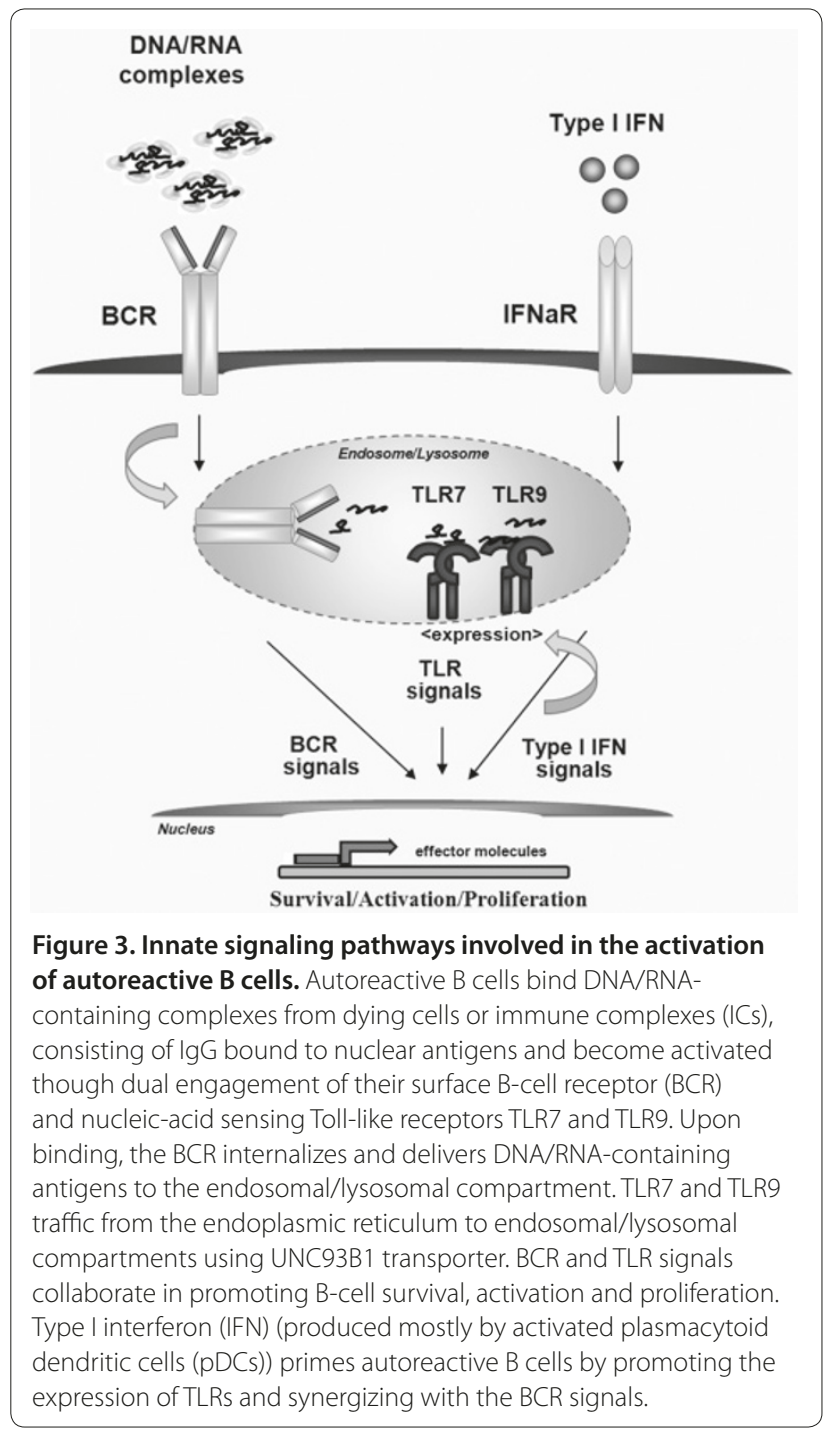

binding receptor, may also regulate TLR responses. TLR8-deficient mice develop spontaneous SLE-like disease, which can be reversed by deletion of TLR7 [86].

Gene-expression profiling of human B cells revealed that both new emigrant and mature naïve B cells express detectable levels of TLR7 and TLR9, but not TLR8. Whether the divergent activities of TLR7 and TLR9 exist in human B cells needs to be investigated. Testing whether abnormalities in UNC93B1 are a risk factor for the development of human SLE will also be of interest. Genetic studies so far support a role for TLR7 and TLR9 in the development of SLE in humans [87-89]. External factors that can influence the induction of TLRs might promote the sensitivity of peripheral B cells to DNAcontaining and RNA-containing antigens and promote the development of SLE. Such stimuli could involve viral infections, UV damage, and so forth. The importance of intrinsic activation of B cells through dual engagement of
BCR/TLRs in human SLE needs further investigation. It should be noted that the effects of TLRs on B-cell functions are not limited to production of autoAbs, but can also stimulate the secretion of proinflammatory cytokines, which can affect the activation of $\mathrm{T}$ cells and amplify the inflammatory responses.

\section{Extrinsic TLR signals: role of type I interferon in the activation of autoreactive $B$ cells}

Increased production of type I interferons (such as IFN $\alpha$ and IFN $\beta$ ) and upregulation of type I interferon-regulated genes (interferon signature) are key features of active SLE disease [90-92] (reviewed in [93-95]). Increased interferon signatures also correlate with the appearance of high-affinity antibodies against nucleic-acid-containing antigens [93,94]. Studies in mice have demonstrated synergistic effects of BCR and interferon signals in activating low-affinity $B$ cells and generation of classswitched antibodies [96]. Recent studies have suggested a model in which type I interferons play a key role in "priming" the B cells by promoting the expression of TLRs. This role seems to be especially important when it comes to TLR7 responses, as murine B cells missing type I interferon receptor respond weakly to TLR7 ligands $[97,98]$. Similarly, human naive B cells require IFN $\alpha$ produced by plasmacytoid dendritic cells (pDCs) to expand and differentiate into immunoglobulin-producing PCs in response to TLR7 ligation in vitro [99]. Both $\mathrm{pDCs}$ and macrophage populations are known, major producers of type I interferons. Uptake of DNA/RNA-associated selfantigen immune complexes can lead to activation of pDCs through TLR9 and TLR7 and induce the production of type I interferons [95]. pDCs therefore play a key role in promoting pathogenic B-cell responses. Increased production of BAFF/BLyS and APRIL by DCs and monocytes is also a possible consequence of increased production of type I interferon by activated pDCs.

\section{B-cell-associated therapeutic targets}

Tremendous strides have been made in B-cell depletionbased therapies to treat a range of autoimmune diseases $[38,100]$. Current and developing therapies include receptor-based therapies to deplete $B$ cells (for example, CD20, CD22), blockade of survival factors (anti-BAFF) and inhibitors to block B-cell signaling and homeostasis (Syk inhibitors). Current and upcoming therapies for SLE have been reviewed recently (for example, [3,101]). Here we highlight therapies that target B-cell signaling pathways.

Current B-cell depletion therapies have derived from a deeper understanding of B-cell biology and markers that define B-cell populations. The fact that autoreactive and autoAb-producing B-lineage cells are sustained and regulated by BCR and TLR signals and by survival factors such as BAFF/BLyS has led to a number of drugs 
targeting B-cell-associated signaling pathways. B-cell survival requires tonic signals through the BCR that are mediated in part by the Syk, Lyn and Btk protein tyrosine kinases and by phosphoinositide 3-kinase. Inhibitors for each of these kinases have been developed and used to successfully treat B-cell cancers such as chronic lymphocytic leukemia [102], and are just beginning to be fully evaluated in patients with autoimmune diseases.

Syk inhibitors affect a number of cell types including B cells and platelets. Phase II clinical trials suggest that an oral Syk inhibitor, R788 (fostamatinib), may be efficacious for the treatment of RA [103]. R788 also delayed disease progression and prolonged survival in NZB/W F1 mice [104] and reduced established skin disease in lupusprone mice [105]. Just how R788 works in vivo is not entirely clear, but in one study where R788 delayed spontaneous diabetes in NOD mice, it also reduced total Bcell numbers and serum immunoglobulin levels while at the same time increasing the numbers of IL-10-producing $B$ cells [106]. Fostamatinib may be more effective at depleting human transitional B cells than mature B cells [107], and thus potentially could be useful for treating autoimmune diseases where RP B cells are a source of autoAb-producing cells.

The fact that mice overexpressing Btk develop a lupuslike disease [20] suggests that Btk inhibitors may be beneficial for treating SLE. The Btk inhibitor PCI-32765 (ibrutinib) selectively blocks BCR-induced activation of human B cells, and in mice inhibits the development of autoAbs, collagen-induced arthritis and lupus-like disease [108]. In a collagen-induced arthritis model, PCI-32765 inhibited a number of different cell types including $\mathrm{B}$ cells, monocytes and macrophages [109]. Whether these encouraging results in mice will be translatable for treatment of human RA and SLE remains to be seen. Many Btk-deficient patients have normal levels of CD21 ${ }^{\text {lo }}$ blood B cells $[8,11]$, implying that Btk inhibitors may not affect RP B-cell-driven autoAb production; further studies are needed to assess this possibility.

Phosphoinositide 3-kinase is activated after BCR ligation and in turn leads to the activation of kinases such as Akt, required for B-cell survival. GS-1101 (CAL-101) reversibly inhibits the phosphoinositide 3-kinase catalytic subunit p110d, which is selectively expressed in B cells. The p110d subunit is an attractive target since p110ddeficient mice have a defect relatively restricted to B cells. Initial clinical trials treating chronic lymphocytic leukemia patients with GS-1101 are very encouraging [102]. Mice with inactive p110d have lower levels of natural autoAbs, and a p110d inhibitor reduces autoAb responses in collagen II-treated rats [110]. Bartok and colleagues reported recently that p110d is expressed in RA synovium, is induced by TNF $\alpha$, and is a regulator of fibroblast growth and survival [111]. Together these studies suggest that p110d inhibitors have the potential to be effective therapies for autoimmune diseases. However, p110d inhibition can also lead to increased production of cytokines such as IL-12 [112] and can affect other cells such as eosinophils, and thus has the potential in some contexts to promote inflammation.

TLR inhibitors are being actively developed and tested for treating autoimmune diseases [113]. Here we wish to note that TLR7/9 inhibitors have the potential to act synergistically with BCR pathway inhibitors to reduce immune complex-driven autoAb production (Figure 3). Also noteworthy is the fact that anti-malarial agents such as hydroxychloquine, which both impair phagolysosomal functions and are TLR antagonists [114], are effective therapeutics for rheumatic diseases such as SLE and RA [115]. Whether and how hydroxychloquine affects B-cell functions in patients with autoimmune diseases is not clear, although this anti-malarial can inhibit BCRinduced calcium mobilization [116] and can induce apoptosis in malignant B cells. Treatment of SLE patients with hydroxychloquine may impair the ability of pDCs in these patients to produce cytokines in response to TLR7 or TLR9 agonists [117]. Hydroxychloquine may also downregulate TLR7 and TLR9 expression in lupus patients, and thus may affect protective immune responses to human papillomavirus [118]. Whether or not these effects can be reduced by a combination of Bcell depletion and TLR inhibition is not known.

We previously proposed that treatment of autoimmune diseases might be improved by combining B-cell depletion therapies with therapies that block or deplete innate immune cells [119]. Certain DC subsets appear to be essential for initiating B-cell maturation into antibodyproducing cells. When antigen is targeted to murine $\mathrm{DCIR}^{+} \mathrm{DCs}$ in the MZ and bridging channels of the spleen, B cells migrate to these DCs, where they are activated and programmed to interact with $\mathrm{T}$ cells and become IgG-producing PCs [64]. While further studies are required to define which $\mathrm{DC}$ subsets promote and sustain autoAb formation, combined B-cell and DC depletion therapy remains an attractive future therapeutic approach. For example, since pDCs selectively express BDCA2, it may be worth assessing the therapeutic benefit of depleting both pDCs (anti-BDCA2) and $\mathrm{B}$ cells (anti-CD20). This could lead to depletion of both pathogenic B cells and IFNo that drives them. Now that B-cell depletion strategies are established, it should be possible to develop the means to deplete diseaseassociated DC populations as well.

\section{Abbreviations}

AFC, antibody-forming cell; AID, activation-induced deaminase; APRIL, a proliferation-inducing ligand; auto Ab, autoantibody; BAFF, B-cell activating factor; $B C R$, B-cell receptor; BM, bone marrow; Btk, Bruton's tyrosine kinase; CD40L, CD40 ligand; CSR, class-switch recombination; DC, dendritic cell; FcyR, 
Fcy receptor; FDC, follicular dendritic cell; GC, germinal center; IL, interleukin; IRAK4, interleukin-1 receptor-associated kinase 4; mAb, monoclonal antibody; MHC, major histocompatibility complex; MZ, marginal zone; PC, plasma cell; PCR, polymerase chain reaction; pDC, plasmacytoid dendritic cell; PTPN22, protein tyrosine phosphatase nonreceptor type 22; RA, rheumatoid arthritis; $\mathrm{RP}$, red pulp; SHM, somatic hypermutation; SLE, systemic lupus erythematosus; TLR, Toll-like receptor; TNF, tumor necrosis factor.

\section{Competing interests}

The authors declare they have no competing interests.

\section{Acknowledgements}

Unpublished observations cited in this manuscript were supported by funding from the National Institutes of Health (R01Al52203, and R37Al44257).

\section{Declarations}

This article has been published as part of Arthritis Research \& Therapy Volume 14 Suppl 4, 2012: New therapeutic targets in systemic lupus erythematosus. The supplement was proposed and developed by the journal. Articles were commissioned by the journal, were independently prepared by the authors and have undergone the journal's standard peer review process. Publication of the supplement has been supported by an unrestricted educational grant from UCB. Completed articles underwent a data quality check by Darwin Healthcare Communications, funded by UCB

\section{Author details}

'Department of Immunology, 1959 NE Pacific Street, University of Washington, Seattle, WA 98195, USA. 'Division of Rheumatology, Department of Medicine, 1959 NE Pacific Street, University of Washington, Seattle, WA 98195, USA.

Published: 2 November 2012

\section{References}

1. Edwards JC, Cambridge G: Prospects for B-cell-targeted therapy in autoimmune disease. Rheumatology (Oxford) 2005, 44:151-156.

2. Nakken B, Munthe LA, Konttinen YT, Sandberg AK, Szekanecz Z, Alex P, Szodoray P: B-cells and their targeting in rheumatoid arthritis - current concepts and future perspectives. Autoimmun Rev 2011, 11:28-34.

3. Yildirim-Toruner C, Diamond B: Current and novel therapeutics in the treatment of systemic lupus erythematosus. J Allergy Clin Immunol 2011, 127:303-312; quiz 313-4.

4. Kuraoka $\mathrm{M}$, Kelsoe $\mathrm{G}$ : A novel role for activation-induced cytidine deaminase: central B-cell tolerance. Cell Cycle 2011, 10:3423-3424.

5. Meffre E: The establishment of early B cell tolerance in humans: lessons from primary immunodeficiency diseases. Ann N Y Acad Sci 2011, 1246:1-10.

6. Pillai S, Mattoo H, Cariappa A: B cells and autoimmunity. Curr Opin Immunol 2011, 23:721-731.

7. Stavnezer J: Complex regulation and function of activation-induced cytidine deaminase. Trends Immunol 2011, 32:194-201.

8. Suryani S, Fulcher DA, Santner-Nanan B, Nanan R, Wong M, Shaw PJ, Gibson J, Williams A, Tangye SG: Differential expression of CD21 identifies developmentally and functionally distinct subsets of human transitional B cells. Blood 2010, 115:519-529.

9. Meffre E, Wardemann H: B-cell tolerance checkpoints in health and autoimmunity. Curr Opin Immunol 2008, 20:632-638.

10. Isnardi I, Ng YS, Menard L, Meyers G, Saadoun D, Srdanovic I, Samuels J, Berman J, Buckner JH, Cunningham-Rundles C, Meffre E: Complement receptor $2 / C D 21^{-}$human naive $B$ cells contain mostly autoreactive unresponsive clones. Blood 2010, 115:5026-5036.

11. Yurasov S, Wardemann H, Hammersen J, Tsuiji M, Meffre E, Pascual V, Nussenzweig MC: Defective B cell tolerance checkpoints in systemic lupus erythematosus. J Exp Med 2005, 201:703-711.

12. Vossenkamper A, Lutalo PM, Spencer J: Translational mini-review series on B cell subsets in disease. Transitional B cells in systemic lupus erythematosus and Sjogren's syndrome: clinical implications and effects of B cell-targeted therapies. Clin Exp Immunol 2012, 167:7-14.

13. Menard L, Saadoun D, Isnardi I, Ng YS, Meyers G, Massad C, Price C, Abraham C, Motaghedi R, Buckner JH, Gregersen PK, Meffre E: The PTPN22 allele encoding an R620W variant interferes with the removal of developing autoreactive B cells in humans. J Clin Invest 2011, 121:3635-3644.
14. Rhee I, Veillette A: Protein tyrosine phosphatases in lymphocyte activation and autoimmunity. Nat Immunol 2012, 13:439-447.

15. Arechiga AF, Habib T, He Y, Zhang X, Zhang ZY, Funk A, Buckner JH: Cutting edge: the PTPN22 allelic variant associated with autoimmunity impairs B cell signaling. J Immunol 2009, 182:3343-3347.

16. Zhang J, Zahir N, Jiang Q, Miliotis H, Heyraud S, Meng X, Dong B, Xie G, Qiu F, Hao Z, McCulloch CA, Keystone EC, Peterson AC, Siminovitch KA: The autoimmune disease-associated PTPN22 variant promotes calpainmediated Lyp/Pep degradation associated with lymphocyte and dendritic cell hyperresponsiveness. Nat Genet 2011, 43:902-907.

17. Horwood NJ, Urbaniak AM, Danks L: Tec family kinases in inflammation and disease. Int Rev Immuno/ 2012, 31:87-103.

18. Fukui R, Saitoh S, Kanno A, Onji M, Shibata T, Ito A, Onji M, Matsumoto M, Akira S, Yoshida N, Miyake K: Unc93B1 restricts systemic lethal inflammation by orchestrating Toll-like receptor 7 and 9 trafficking. Immunity 2011 , 35:69-81.

19. Itoh H, Tatematsu M, Watanabe A, Iwano K, Funami K, Seya T, Matsumoto M: UNC93B1 physically associates with human TLR8 and regulates TLR8mediated signaling. PLoS One 2011, 6:e28500.

20. Kil LP, de Bruijn MJ, van Nimwegen M, Corneth OB, van Hamburg JP, Dingjan GM, Thaiss F, Rimmelzwaan GF, Elewaut D, Delsing D, van Loo PF, Hendriks RW: Btk levels set the threshold for B-cell activation and negative selection of autoreactive B cells in mice. Blood 2011, 119:3744-3756.

21. Mackay F, Silveira PA, Brink R: B cells and the BAFF/APRIL axis: fast-forward on autoimmunity and signaling. Curr Opin Immunol 2007, 19:327-336.

22. Liu Z, Davidson A: BAFF and selection of autoreactive B cells. Trends Immunol 2011, 32:388-394.

23. Groom JR, Fletcher CA, Walters SN, Grey ST, Watt SV, Sweet MJ, Smyth MJ, Mackay CR, Mackay F: BAFF and MyD88 signals promote a lupuslike disease independent of T cells. J Exp Med 2007, 204:1959-1971.

24. Bombardieri M, Kam NW, Brentano F, Choi K, Filer A, Kyburz D, Mclnnes IB, Gay S, Buckley C, Pitzalis C: A BAFF/APRIL-dependent TLR3-stimulated pathway enhances the capacity of rheumatoid synovial fibroblasts to induce AID expression and lg class-switching in B cells. Ann Rheum Dis 2011, 70:1857-1865.

25. Acosta-Rodriguez EV, Craxton A, Hendricks DW, Merino MC, Montes CL, Clark EA, Gruppi A: BAFF and LPS cooperate to induce $B$ cells to become susceptible to CD95/Fas-mediated cell death. Eur J Immuno/ 2007, 37:990-1000.

26. Chappell CP, Jacob J: Germinal-center-derived B-cell memory. Adv Exp Med Biol 2007, 590:139-148.

27. Goodnow CC, Vinuesa CG, Randall KL, Mackay F, Brink R: Control systems and decision making for antibody production. Nat Immunol 2010, 11:681-688.

28. Tiller T, Kofer J, Kreschel C, Busse CE, Riebel S, Wickert S, Oden F, Mertes MM, Ehlers $\mathrm{M}$, Wardemann $\mathrm{H}$ : Development of self-reactive germinal center $\mathrm{B}$ cells and plasma cells in autoimmune FcyRIIIB-deficient mice. J Exp Med 2010, 207:2767-2778.

29. Guo W, Smith D, Aviszus K, Detanico T, Heiser RA, Wysocki L: Somatic hypermutation as a generator of antinuclear antibodies in a murine model of systemic autoimmunity. J Exp Med 2010, 207:2225-2237.

30. Mietzner B, Tsuiji M, Scheid J, Velinzon K, Tiller T, Abraham K, Gonzalez JB, Pascual V, Stichweh D, Wardemann H, Nussenzweig MC: Autoreactive IgG memory antibodies in patients with systemic lupus erythematosus arise from nonreactive and polyreactive precursors. Proc Natl Acad Sci U S A 2008, 105:9727-9732.

31. Tiller T, Tsuiji M, Yurasov S, Velinzon K, Nussenzweig MC, Wardemann H: Autoreactivity in human lgG $\mathrm{G}^{+}$memory B cells. Immunity 2007, 26:205-213.

32. Linterman MA, Rigby RJ, Wong RK, Yu D, Brink R, Cannons JL, Schwartzberg $\mathrm{PL}$, Cook MC, Walters GD, Vinuesa CG: Follicular helper T cells are required for systemic autoimmunity. J Exp Med 2009, 206:561-576.

33. Vuyyuru R, Mohan C, Manser T, Rahman ZS: The lupus susceptibility locus Sle1 breaches peripheral $B$ cell tolerance at the antibody-forming cell and germinal center checkpoints. J Immunol 2009, 183:5716-5727.

34. Scheid JF, Mouquet $\mathrm{H}$, Kofer J, Yurasov S, Nussenzweig MC, Wardemann H: Differential regulation of self-reactivity discriminates between $\lg \mathrm{G}^{+}$ human circulating memory $B$ cells and bone marrow plasma cells. Proc Natl Acad Sci U S A 2011, 108:18044-18048.

35. Chappell CP, Jacob J: Identification of memory B cells using a novel transgenic mouse model. J Immuno/ 2006, 176:4706-4715.

36. Blink EJ, Light A, Kallies A, Nutt SL, Hodgkin PD, Tarlinton DM: Early appearance of germinal center-derived memory $B$ cells and plasma cells 
in blood after primary immunization. J Exp Med 2005, 201:545-554.

37. Arbuckle MR, McClain MT, Rubertone MV, Scofield RH, Dennis GJ, James JA, Harley JB: Development of autoantibodies before the clinical onset of systemic lupus erythematosus. N Eng/J Med 2003, 349:1526-1533.

38. Townsend MJ, Monroe JG, Chan AC: B-cell targeted therapies in human autoimmune diseases: an updated perspective. Immunol Rev 2010, 237:264-283.

39. Mao C, Jiang L, Melo-Jorge M, Puthenveetil M, Zhang X, Carroll MC, ImanishiKari T: $T$ cell-independent somatic hypermutation in murine $B$ cells with an immature phenotype. Immunity 2004, 20:133-144.

40. Han JH, Akira S, Calame K, Beutler B, Selsing E, Imanishi-Kari T: Class switch recombination and somatic hypermutation in early mouse $B$ cells are mediated by B cell and Toll-like receptors. Immunity 2007, 27:64-75.

41. Ueda Y, Liao D, Yang K, Patel A, Kelsoe G: T-independent activation-induced cytidine deaminase expression, class-switch recombination, and antibody production by immature/transitional 1 B cells. J Immuno/ 2007, 178:3593-3601.

42. Aranburu A, Ceccarelli S, Giorda E, Lasorella R, Ballatore G, Carsetti R: TLR ligation triggers somatic hypermutation in transitional $B$ cells inducing the generation of IgM memory B cells. J Immunol 2010, 185:7293-7301.

43. Guo P, Hirano M, Herrin BR, Li J, Yu C, Sadlonova A, Cooper MD: Dual nature of the adaptive immune system in lampreys. Nature 2009, 459:796-801

44. Meyers G, Ng YS, Bannock JM, Lavoie A, Walter JE, Notarangelo LD, Kilic SS, Aksu G, Debre M, Rieux-Laucat F, Conley ME, Cunningham-Rundles C, Durandy A, Meffre E: Activation-induced cytidine deaminase (AID) is required for B-cell tolerance in humans. Proc Natl Acad Sci U S A 2011, 108:11554-11559.

45. Kuraoka M, Holl TM, Liao D, Womble M, Cain DW, Reynolds AE, Kelsoe G: Activation-induced cytidine deaminase mediates central tolerance in B cells. Proc Natl Acad Sci U S A 2011, 108:11560-11565.

46. William J, Euler C, Christensen S, Shlomchik MJ: Evolution of autoantibody responses via somatic hypermutation outside of germinal centers. Science 2002, 297:2066-2070.

47. Sweet RA, Ols ML, Cullen JL, Milam AV, Yagita H, Shlomchik MJ: Facultative role for T cells in extrafollicular Toll-like receptor-dependent autoreactive B-cell responses in vivo. Proc Natl Acad Sci U S A 2011, 108:7932-7937.

48. He B, Qiao X, Cerutti A: CpG DNA induces IgG class switch DNA recombination by activating human $B$ cells through an innate pathway that requires TLR9 and cooperates with IL-10. J Immunol 2004, 173:4479-4491.

49. Litinskiy MB, Nardelli B, Hilbert DM, He B, Schaffer A, Casali P, Cerutti A: DCs induce CD40-independent immunoglobulin class switching through BLyS and APRIL. Nat Immunol 2002, 3:822-829.

50. He B, Santamaria R, Xu W, Cols M, Chen K, Puga I, Shan M, Xiong H, Bussel JB, Chiu A, Puel A, Reichenbach J, Marodi L, Doffinger R, Vasconcelos J, Issekutz A, Krause J, Davies G, Li X, Grimbacher B, Plebani A, Meffre E, Picard C, Cunningham-Rundles C, Casanova JL, Cerutti A: The transmembrane activator TACl triggers immunoglobulin class switching by activating $B$ cells through the adaptor MyD88. Nat Immuno/ 2010, 11:836-845.

51. Ngo VN, Korner H, Gunn MD, Schmidt KN, Riminton DS, Cooper MD, Browning JL, Sedgwick JD, Cyster JG: Lymphotoxin alpha/beta and tumor necrosis factor are required for stromal cell expression of homing chemokines in B and T cell areas of the spleen. J Exp Med 1999, 189:403-412.

52. Hamaguchi Y, Uchida J, Cain DW, Venturi GM, Poe JC, Haas KM, Tedder TF: The peritoneal cavity provides a protective niche for $\mathrm{B} 1$ and conventional B lymphocytes during anti-CD20 immunotherapy in mice. J Immuno/ 2005, 174:4389-4399.

53. Astorri E, Bombardieri M, Gabba S, Peakman M, Pozzilli P, Pitzalis C: Evolution of ectopic lymphoid neogenesis and in situ autoantibody production in autoimmune nonobese diabetic mice: cellular and molecular characterization of tertiary lymphoid structures in pancreatic islets. J Immunol 2010, 185:3359-3368.

54. Humby F, Bombardieri M, Manzo A, Kelly S, Blades MC, Kirkham B, Spencer J, Pitzalis $C$ : Ectopic lymphoid structures support ongoing production of class-switched autoantibodies in rheumatoid synovium. PLOS Med 2009, 6:e1.

55. Victora GD, Nussenzweig MC: Germinal centers. Annu Rev /mmuno/ 2012 , 30:429-457.

56. Dudziak D, Kamphorst AO, Heidkamp GF, BuchholzVR, Trumpfheller C, Yamazaki S, Cheong C, Liu K, Lee HW, Park CG, Steinman RM, Nussenzweig
MC: Differential antigen processing by dendritic cell subsets in vivo. Science 2007, 315:107-111.

57. Sancho D, Joffre OP, Keller AM, Rogers NC, Martinez D, Hernanz-Falcon P, Rosewell I, Reis e Sousa C: Identification of a dendritic cell receptor that couples sensing of necrosis to immunity. Nature 2009, 458:899-903.

58. Gaipl US, Voll RE, Sheriff A, Franz S, Kalden JR, Herrmann M: Impaired clearance of dying cells in systemic lupus erythematosus. Autoimmun Rev 2005, 4:189-194.

59. Jego G, Pascual V, Palucka AK, Banchereau J: Dendritic cells control B cell growth and differentiation. Curr Dir Autoimmun 2005, 8:124-139.

60. Tangye SG: Plasmacytoid DCs induce gutsy plasma cells. Immunity 2011, 34:144-146.

61. Bergtold A, Desai DD, Gavhane A, Clynes R: Cell surface recycling of internalized antigen permits dendritic cell priming of B cells. Immunity 2005, 23:503-514.

62. Qi H, Egen JG, Huang AY, Germain RN: Extrafollicular activation of lymph node B cells by antigen-bearing dendritic cells. Science 2006, 312:1672-1676.

63. Teichmann LL, Ols ML, Kashgarian M, Reizis B, Kaplan DH, Shlomchik MJ: Dendritic cells in lupus are not required for activation of $T$ and $B$ cells but promote their expansion, resulting in tissue damage. Immunity 2010, 33:967-978.

64. Chappell CP, Draves KE, Giltiay NV, Clark EA: Extrafollicular B cell activation by marginal zone dendritic cells drives $\mathrm{T}$ cell-dependent antibody responses. J Exp Med 2012, in press. [Epub ahead of print]

65. Green NM, Marshak-Rothstein A: Toll-like receptor driven B cell activation in the induction of systemic autoimmunity. Semin Immuno/ 2011, 23:106-112.

66. Lau CM, Broughton C, Tabor AS, Akira S, Flavell RA, Mamula MJ, Christensen SR, Shlomchik MJ, Viglianti GA, Rifkin IR, Marshak-Rothstein A: RNAassociated autoantigens activate $B$ cells by combined $B$ cell antigen receptor/Toll-like receptor 7 engagement. J Exp Med 2005, 202:1171-1177.

67. Leadbetter EA, Rifkin IR, Hohlbaum AM, Beaudette BC, Shlomchik MJ, Marshak-Rothstein A: Chromatin-lgG complexes activate B cells by dual engagement of IgM and Toll-like receptors. Nature 2002, 416:603-607.

68. Viglianti GA, Lau CM, Hanley TM, Miko BA, Shlomchik MJ, Marshak-Rothstein A: Activation of autoreactive B cells by CpG dsDNA. Immunity 2003, 19:837-847.

69. Bijl M, Reefman E, Horst G, Limburg PC, Kallenberg CG: Reduced uptake of apoptotic cells by macrophages in systemic lupus erythematosus: correlates with decreased serum levels of complement. Ann Rheum Dis 2006, 65:57-63.

70. Ren Y, Tang J, Mok MY, Chan AW, Wu A, Lau CS: Increased apoptotic neutrophils and macrophages and impaired macrophage phagocytic clearance of apoptotic neutrophils in systemic lupus erythematosus. Arthritis Rheum 2003, 48:2888-2897.

71. Uccellini MB, Busconi L, Green NM, Busto P, Christensen SR, Shlomchik MJ, Marshak-Rothstein A, Viglianti GA: Autoreactive B cells discriminate CpGrich and $\mathrm{CpG}$-poor DNA and this response is modulated by IFN-alpha. J Immunol 2008, 181:5875-5884.

72. Ballestar E: Epigenetic alterations in autoimmune rheumatic diseases. Nat Rev Rheumatol 2011, 7:263-271.

73. Diebold SS: Recognition of viral single-stranded RNA by Toll-like receptors. Adv Drug Deliv Rev 2008, 60:813-823.

74. Cyster JG: B cell follicles and antigen encounters of the third kind. Nat Immunol 2010, 11:989-996.

75. Hakkim A, Furnrohr BG, Amann K, Laube B, Abed UA, Brinkmann V, Herrmann $M$, Voll RE, Zychlinsky A: Impairment of neutrophil extracellular trap degradation is associated with lupus nephritis. Proc Natl Acad Sci U S A 2010, 107:9813-9818.

76. Puga I, Cols M, Barra CM, He B, Cassis L, Gentile M, Comerma L, Chorny A, Shan M, Xu W, Magri, G Knowles DM, Tam W, Chiu A, Bussel JB, Serrano S, Lorente JA, Bellosillo B, Lloreta J, Juanpere N, Alameda F, Baro T, de Heredia CD, Toran N, Catala A, Torrebadell M, Fortuny C, Cusi V, Carreras C, Diaz GA, et al:: $B$ cell-helper neutrophils stimulate the diversification and production of immunoglobulin in the marginal zone of the spleen. Nat Immunol 2012 13:170-180.

77. Giltiay NV: TLR7 overexpression drives autoantigen-mediated expansion of transitional and follicular B cells independently of type I IFN signals [abstract]. Arthritis Rheum 2011, 63 (Suppl 10):2548.

78. Latz E, Schoenemeyer A, Visintin A, Fitzgerald KA, Monks BG, Knetter CF, Lien E, Nilsen NJ, Espevik T, Golenbock DT: TLR9 signals after translocating from 
the ER to CpG DNA in the lysosome. Nat Immuno/ 2004, 5:190-198.

79. Chaturvedi A, Dorward D, Pierce SK: The B cell receptor governs the subcellular location of Toll-like receptor 9 leading to hyperresponses to DNA-containing antigens. Immunity 2008, 28:799-809.

80. Saitoh S, Miyake K: Regulatory molecules required for nucleotide-sensing Toll-like receptors. Immunol Rev 2009, 227:32-43.

81. Christensen SR, Shupe J, Nickerson K, Kashgarian M, Flavell RA, Shlomchik MJ: Toll-like receptor 7 and TLR9 dictate autoantibody specificity and have opposing inflammatory and regulatory roles in a murine model of lupus. Immunity 2006, 25:417-428.

82. Pisitkun P, Deane JA, Difilippantonio MJ, Tarasenko T, Satterthwaite AB, Bolland S: Autoreactive B cell responses to RNA-related antigens due to TLR7 gene duplication. Science 2006, 312:1669-1672.

83. Deane JA, Pisitkun P, Barrett RS, Feigenbaum L, Town T, Ward JM, Flavell RA, Bolland S: Control of toll-like receptor 7 expression is essential to restrict autoimmunity and dendritic cell proliferation. Immunity 2007, 27:801-810

84. Christensen SR, Kashgarian M, Alexopoulou L, Flavell RA, Akira S, Shlomchik MJ: Toll-like receptor 9 controls anti-DNA autoantibody production in murine lupus. J Exp Med 2005, 202:321-331.

85. Santiago-Raber ML, Dunand-Sauthier I, Wu T, Li QZ, Uematsu S, Akira S, Reith W, Mohan C, Kotzin BL, Izui S: Critical role of TLR7 in the acceleration of systemic lupus erythematosus in TLR9-deficient mice. J Autoimmun 2010, 34:339-348.

86. Demaria O, Pagni PP, Traub S, de Gassart A, Branzk N, Murphy AJ, Valenzuela DM, Yancopoulos GD, Flavell RA, Alexopoulou L: TLR8 deficiency leads to autoimmunity in mice. J Clin Invest 2010, 120:3651-3662.

87. Kawasaki A, Furukawa H, Kondo Y, Ito S, Hayashi T, Kusaoi M, Matsumoto I, Tohma S, Takasaki Y, Hashimoto H, Sumida T, Tsuchiya N: TLR7 singlenucleotide polymorphisms in the $3^{\prime}$ untranslated region and intron 2 independently contribute to systemic lupus erythematosus in Japanese women: a case-control association study. Arthritis Res Ther 2011, 13:R41.

88. Shen N, Fu Q, Deng Y, Qian X, Zhao J, Kaufman KM, Wu YL, Yu CY, Tang Y, Chen JY, Yang W, Wong M, Kawasaki A, Tsuchiya N, Sumida T, Kawaguchi Y, Howe HS, Mok MY, Bang SY, Liu FL, Chang DM, Takasaki Y, Hashimoto H, Harley JB, Guthridge JM, Grossman JM, Cantor RM, Song YW, Bae SC, Chen S, et al:: Sex-specific association of X-linked Toll-like receptor 7 (TLR7) with male systemic lupus erythematosus. Proc Natl Acad Sci U S A 2010, 107:15838-15843.

89. Tao K, Fujii M, Tsukumo S, Maekawa Y, Kishihara K, Kimoto Y, Horiuchi T, Hisaeda H, Akira S, Kagami S, Yasutomo K: Genetic variations of Toll-like receptor 9 predispose to systemic lupus erythematosus in Japanese population. Ann Rheum Dis 2007, 66:905-909.

90. Friedman RM, Preble O, Black R, Harrell S: Interferon production in patients with systemic lupus erythematosus. Arthritis Rheum 1982, 25:802-803.

91. Hooks JJ, Jordan GW, Cupps T, Moutsopoulos HM, Fauci AS, Notkins AL: Multiple interferons in the circulation of patients with systemic lupus erythematosus and vasculitis. Arthritis Rheum 1982, 25:396-400

92. Preble OT, Black RJ, Friedman RM, Klippel JH, Vilcek J: Systemic lupus erythematosus: presence in human serum of an unusual acid-labile leukocyte interferon. Science 1982, 216:429-431.

93. Elkon KB, Stone W: Type I interferon and systemic lupus erythematosus. J Interferon Cytokine Res 2011, 31:803-812.

94. Ronnblom L: The type I interferon system in the etiopathogenesis of autoimmune diseases. Ups J Med Sci 2011, 116:227-237.

95. Pascual V, Farkas L, Banchereau J: Systemic lupus erythematosus: all roads lead to type I interferons. Curr Opin Immunol 2006, 18:676-682.

96. Swanson CL, Wilson TJ, Strauch P, Colonna M, Pelanda R, Torres RM: Type I IFN enhances follicular B cell contribution to the T cell-independent antibody response. J Exp Med 2010, 207:1485-1500.

97. Green NM, Laws A, Kiefer K, Busconi L, Kim YM, Brinkmann MM, Trail EH, Yasuda K, Christensen SR, Shlomchik MJ, Vogel S, Connor JH, Ploegh H, Eilat D, Rifkin IR, van Seventer JM, Marshak-Rothstein A: Murine B cell response to TLR7 ligands depends on an IFN-beta feedback loop. J Immuno/ 2009, 183:1569-1576

98. Thibault DL, Chu AD, Graham KL, Balboni I, Lee LY, Kohlmoos C, Landrigan A, Higgins JP, Tibshirani R, Utz PJ: IRF9 and STAT1 are required for IgG autoantibody production and B cell expression of TLR7 in mice. J Clin Invest 2008, 118:1417-1426.

99. Bekeredjian-Ding IB, Wagner M, Hornung V, Giese T, Schnurr M, Endres S, Hartmann G: Plasmacytoid dendritic cells control TLR7 sensitivity of naive B cells via type I IFN. J Immunol 2005, 174:4043-4050.
100. Rosado MM, Diamanti AP, Capolunghi F, Carsetti R: B cell modulation strategies in autoimmunity: the SLE example. Curr Pharm Des 2011, 17:3155-3165.

101. Marian V, Anolik JH: Treatment targets in systemic lupus erythematosus: biology and clinical perspective. Arthritis Res Therapy 2012, 14(Suppl 4):S3.

102. Woyach JA, Johnson AJ, Byrd JC: The B-cell receptor signaling pathway as a therapeutic target in CLL. Blood 2012, 120:1175-1184.

103. Scott DL: Role of spleen tyrosine kinase inhibitors in the management of rheumatoid arthritis. Drugs 2011, 71:1121-1132.

104. Bahjat FR, Pine PR, Reitsma A, Cassafer G, Baluom M, Grillo S, Chang B, Zhao FF, Payan DG, Grossbard EB, Daikh DI: An orally bioavailable spleen tyrosine kinase inhibitor delays disease progression and prolongs survival in murine lupus. Arthritis Rheum 2008, 58:1433-1444.

105. Deng GM, Liu L, Bahjat FR, Pine PR, Tsokos GC: Suppression of skin and kidney disease by inhibition of spleen tyrosine kinase in lupus-prone mice. Arthritis Rheum 2010, 62:2086-2092.

106. Colonna L, Catalano G, Chew C, D'Agati V, Thomas JW, Wong FS, Schmitz J, Masuda ES, Reizis B, Tarakhovsky A, Clynes R: Therapeutic targeting of Syk in autoimmune diabetes. J Immunol 2010, 185:1532-1543.

107. Barr PM, Wei C, Roger J, Schaefer-Cutillo J, Kelly JL, Rosenberg AF, Jung J, Sanz I, Friedberg JW: Syk inhibition with fostamatinib leads to transitional B lymphocyte depletion. Clin Immunol 2012, 142:237-242.

108. Honigberg LA, Smith AM, Sirisawad M, Verner E, Loury D, Chang B, Li S, Pan Z, Thamm DH, Miller RA, Buggy JJ: The Bruton tyrosine kinase inhibitor PCl-32765 blocks B-cell activation and is efficacious in models of autoimmune disease and B-cell malignancy. Proc Natl Acad Sci U S A 2010, 107:13075-13080.

109. Chang BY, Huang MM, Francesco M, Chen J, Sokolove J, Magadala P, Robinson WH, Buggy JJ: The Bruton tyrosine kinase inhibitor PCl-32765 ameliorates autoimmune arthritis by inhibition of multiple effector cells. Arthritis Res Ther 2011, 13:R115.

110. Durand CA, Hartvigsen K, Fogelstrand L, Kim S, Iritani S, Vanhaesebroeck B, Witztum JL, Puri KD, Gold MR: Phosphoinositide 3-kinase p110 delta regulates natural antibody production, marginal zone and B-1 B cell function, and autoantibody responses. J Immuno/ 2009, 183:5673-5684.

111. Bartok B, Boyle DL, Liu Y, Ren P, Ball ST, Bugbee WD, Rommel C, Firestein GS $\mathrm{PI} 3$ kinase delta is a key regulator of synoviocyte function in rheumatoid arthritis. Am J Pathol 2012, 180:1906-1916.

112. Dil N, Marshall AJ: Role of phosphoinositide 3-kinase p110 delta in TLR4and TLR9-mediated B cell cytokine production and differentiation. Mol Immunol 2009, 46:1970-1978.

113. Hennessy EJ, Parker AE, O'Neill LA: Targeting Toll-like receptors: emerging therapeutics? Nat Rev Drug Discov 2010, 9:293-307.

114. Katz SJ, Russell AS: Re-evaluation of antimalarials in treating rheumatic diseases: re-appreciation and insights into new mechanisms of action. Curr Opin Rheumatol 2011, 23:278-281.

115. Lee SJ, Silverman E, Bargman JM: The role of antimalarial agents in the treatment of SLE and lupus nephritis. Nat Rev Nephrol 2011, 7:718-729.

116. Goldman FD, Gilman AL, Hollenback C, Kato RM, Premack BA, Rawlings DJ: Hydroxychloroquine inhibits calcium signals in T cells: a new mechanism to explain its immunomodulatory properties. Blood 2000, 95:3460-3466.

117. Sacre K, Criswell LA, McCune JM: Hydroxychloroquine is associated with impaired interferon-alpha and tumor necrosis factor-alpha production by plasmacytoid dendritic cells in systemic lupus erythematosus. Arthritis Res Ther 2012, 14:R155.

118. Yu SL, Chan PK, Wong CK, Szeto CC, Ho SC, So K, Yu MM, Yim SF, Cheung TH, Wong MC, Cheung JL, Yeung AC, Li EK, Tam LS: Antagonist-mediated downregulation of toll-like receptors increases the prevalence of human papillomavirus infection in systemic lupus erythematosus. Arthritis Res Ther 2012, 14:R80.

119. Clark EA, Ledbetter JA: How does B cell depletion therapy work, and how can it be improved? Ann Rheum Dis 2005, 64(Suppl 4):iv77-iv80.

doi:10.1186/ar3918

Cite this article as: Giltiay NV, et al:: B-cell selection and the development of autoantibodies. Arthritis Research \& Therapy 2012, 14(Suppl 4):S1. 